\title{
Escherichia coli metabolism in space
}

\author{
PhILIPPE Bouloc* and RiCHARD D’ARI \\ Institut Jacques Monod, Centre Nationale de la Recherche Scientifique, Université Paris 7, 2 place Jussieu, \\ 75251 Paris Cedex 05, France
}

(Received 3 June 1991; revised 6 August 1991; accepted 12 September 1991)

\begin{abstract}
Cultures of the bacterium Escherichia coli were grown in the orbiting Biocosmos 2044 satellite in order to evaluate the effects of the space environment - weightlessness and heavy particle radiation - on growth parameters and energy metabolism, which have previously been reported to be affected, and on induction of the SOS response, which reflects DNA damage to the cell. We found no differences between the flight samples and control ground cultures in the growth yield per gram of carbon, in mean cell mass (from which we deduce that the growth rate was unaltered) or in the level of expression of the SOS response. These observations indicate that free-growing bacterial cells do not expend significant energy fighting gravity and that cosmic radiation within a space capsule does not produce significant levels of DNA damage.
\end{abstract}

\section{Introduction}

In the Soviet space satellite Biocosmos 2044, which orbited the earth from September 15-30 1989, we grew cultures of the bacterium Escherichia coli. We wished to evaluate the effects of weightlessness and heavy particle radiation, characteristic of the space environment, on cell growth parameters and energy metabolism, which were previously reported to be affected in space, and on induction of the SOS response, which is induced by DNA damage to the cell. We measured the growth yield per gram of carbon, the mean cell mass (from which we can deduce the growth rate), and the level of expression of the SOS response, to evaluate the degree of genotoxicity.

The environment in a pressurized, thermostated space cabin is characterized by the near absence of gravity ('microgravity') and by the presence of heavy particle (cosmic) radiation. A number of experiments have demonstrated certain effects of this environment on whole organisms. The effects on individual cells, however, are controversial (Gmünder \& Cogoli, 1988). In a physiological study of a culture of embryonic human lung cells, Montgomery et al. (1978) reported that growth rate, cell shape, organelle position, post-growth medium composition and karyotype were not modified by growth in space. Cogoli et al. (1984) investigated the effect of weightlessness on immune cell differentiation; they reported weak activation of in vitro cultures of lymphocytes with concanavalin A, compared to the ground control. In experiments carried out on the same flight as ours, L. Schaffar and collaborators observed a drastic inhibition of the activation of interleukin 1 and interleukin 2 by phorbol esters, compared to the ground controls (Limouse et al., 1991).

Growth of unicellular organisms in space has also been studied, although the variety of organisms and techniques used makes it difficult to compare the different results. Richoilley et al. (1986) reported that Paramecium tetraurelia proliferated faster in microgravity. Menigmann \& Lange (1986) reported similar results with Bacillus subtilis, with higher cell mass production in microgravity. It has been suggested that the faster proliferation observed in space is due to an economy of cell energy normally expended on 'uphill' motility.

The quantification of radiation hazards in a space capsule has been a problem (Letaw et al., 1987). Cosmic radiation covers a broad spectrum, including highenergy protons, alpha particles and heavier particles, which can penetrate the satellite; organisms on earth are protected by the ionosphere. This spectrum is difficult to reproduce on the ground and its biological effects are consequently difficult to evaluate.

A series of simple experiments was designed to be carried out in an unmanned satellite, such as Biocosmos 2044 , to evaluate growth yields, growth rates and the degree of genotoxicity in the space environment. As biological material we chose the well-studied bacterium Escherichia coli. 


\section{Methods}

Strains. For the growth yield and physiological experiments the $E$. coli strain GC2852 was used; it is the prototrophic K12 strain W3110 carrying a gene conferring kanamycin resistance $(s r l:: T n 5)$. The experiments on SOS induction were carried out with strain GC4415 (D’Ari \& Huisman, 1983), which carries a sfi : : lacZ operon fusion (placing the structural gene of the enzyme $\beta$-galactosidase under control of the SOS-inducible gene sfiA); the chromosomal lac operon is deleted, and the strain carries a gene conferring tetracycline resistance (srl: : in 10 ).

Media. Minimal medium, used in the growth yield and physiology experiments, was M63 (Miller, 1972) supplemented with glucose or glycerol and containing $40 \mu \mathrm{g}$ kanamycin $\mathrm{ml}^{-1}$. The experiments on SOS induction were carried out in LB broth (Miller, 1972) containing $10 \mu \mathrm{g}$ tetracycline $\mathrm{ml}^{-1}$.

Experimental methods. Optical density of bacterial cultures was measured at $600 \mathrm{~nm}$ with a Gilford spectrophotometer. Protein concentration was measured by the method of Bradford (1976). $\beta$-Galactosidase was assayed as described in Miller (1972); specific activity is expressed with respect to the $\mathrm{OD}_{600}$ of the culture. Cell number and volume distribution were determined with a Coulter counter (model Z) equipped with a $30 \mu \mathrm{m}$ orifice and a $\mathrm{Cl} 1000$ Channelyzer. Hypergravity experiments were performed on a lowspeed centrifuge specially constructed for this purpose; samples in polypropylene bags are attached to rectangular plates at two different radii, providing a total acceleration vector of 3 and $5 g$; in addition, the plates could be made to rotate slowly around a horizontal axis to prevent sedimentation of bacteria against the wall of the bag.

Experimental protocol. Samples $(10 \mu \mathrm{l})$ of overnight bacterial cultures were sealed in glass ampoules; for the experiments on SOS induction, $10 \mu \mathrm{l}$ samples of a chloramphenicol solution were similarly sealed. The glass ampoules were attached to a plastic matrix and placed in polypropylene bags, together with the appropriate growth medium. The bags were then sealed. All operations were carried out aseptically. The bags were stored at $-70^{\circ} \mathrm{C}$. On September 10 th the samples were transported to Moscow in dry-ice and arbitrarily divided into flight and ground sets, with each experimental point represented in triplicate in each set. On September 11 th the samples were transferred to two portable incubators at $37^{\circ} \mathrm{C}$, one of which was transported to the launching site at Plessetsk. On September 13 th the samples were placed in Cytos incubators at $37^{\circ} \mathrm{C}$. On September 15th at 6:30 GMT the satellite was launched into a nearly polar orbit; at 13:44 GMT, timezero of the experiment, the programmed sequence was triggered and the ampoules containing the bacterial inocula were broken. The ground experiments were triggered $4 \mathrm{~h}$ later, when a signal from the satellite confirmed initiation of the flight experiments. The experiments were stopped by lowering the Cytos temperature to $4{ }^{\circ} \mathrm{C}$ at time $24 \mathrm{~h}$; the temperature transition took less than $4 \mathrm{~h}$. The satellite landed in Kazakhstan on September 30th. The samples, maintained at $4{ }^{\circ} \mathrm{C}$, were transported to Paris via Moscow. All analyses were carried out between October 2nd and 7th.

\section{Results and Discussion}

\section{Growth yield}

Carbon sources in the growth medium provide raw material and energy for $E$. coli. The growth yield is a direct measure of the efficiency with which the carbon is

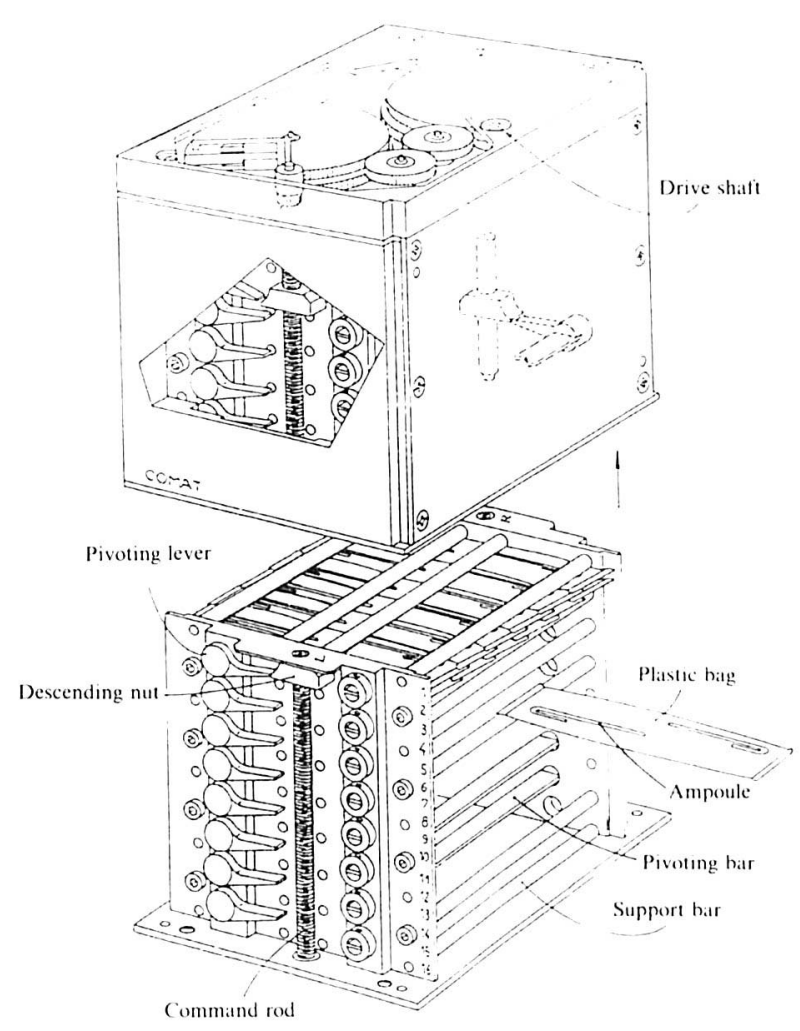

Fig. 1. Biological container for the Cytos automatic incubator. The container holds 96 double layer $1 \times 7 \mathrm{~cm}$ plastic bags of volume $1 \mathrm{ml}$ containing biological samples and up to two sealed glass capillary tubes, or ampoules, containing 10 to $20 \mu$ l of solution. The sacks are held in eight double layers by support bars. For each double layer, there are two pivoting bars, front and back (two of the front bars are visible in the diagram), passing between the two layers. When a given bar pivots, it breaks all ampoules touching it (up to 12 ampoules), ejecting the solution into the culture; the ampoules contain air under pressure at each end of the liquid column, ensuring rapid expulsion of the liquid on breakage (Tixador $e t$ al., 1981). Each pivoting bar is fixed to a pivoting lever at one end. The levers are turned by a descending nut, which is moved downwards by rotation of the corresponding command rod. There are two command rods, right and left, governing the breakage of the front and back ampoules, respectively, and permitting injection into the culture at two different times in the experiment. The command rods are in turn rotated by the drive shaft. Depending on the sense of rotation of the drive shaft, one or other command rod is rotated. The dimensions of the container are $119 \times 99 \times 84 \mathrm{~mm}$. It is placed in the Cytos incubator, which ensures thermoregulation and provides the driving motor. All operations are commanded automatically according to a pre-programmed schedule.

utilized. It is readily evaluated by cultivating cells in a medium in which the carbon source is limiting, then measuring the saturating concentration of biomass as a function of the carbon concentration; strict linearity is observed. To carry out such experiments in the satellite, we prepared the media with limiting carbon source, sealed the bacteria in glass ampoules, then placed ampoules and medium together in polypropylene bags which fit in the container of the Cytos automatic incubator (Fig. 1). The cultures were inoculated in orbit 
(a)

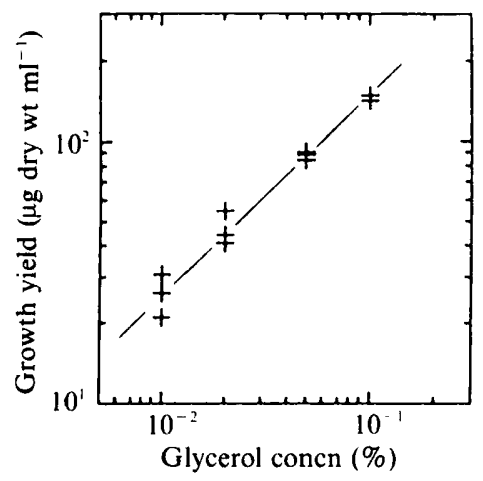

(c)

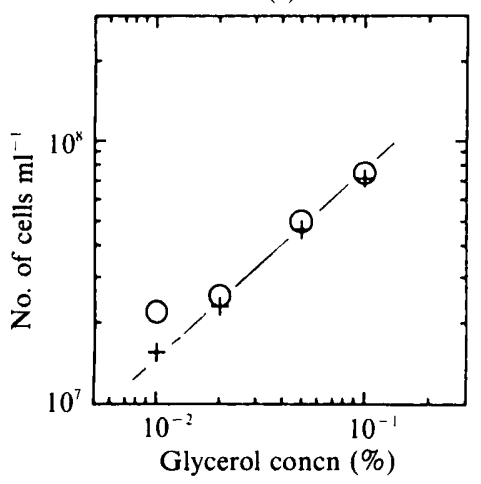

(b)

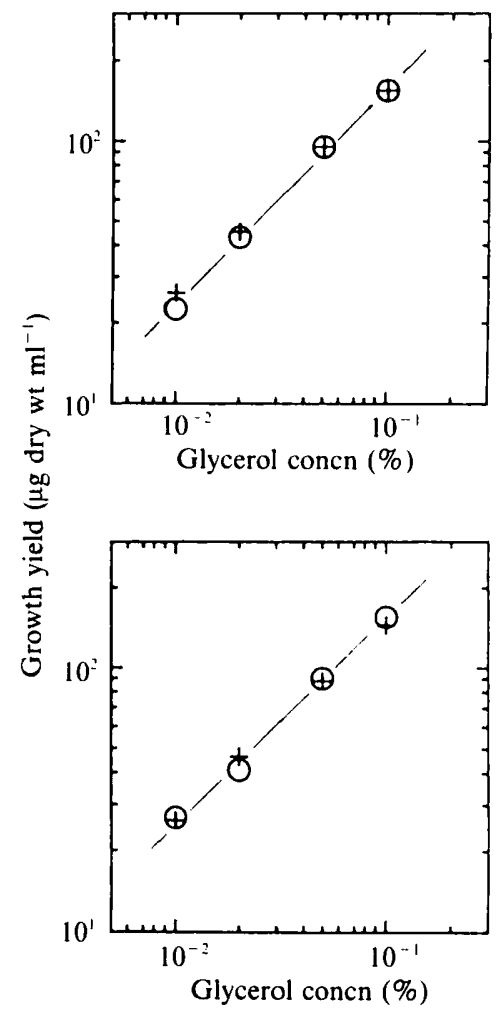

Fig. 2. Bacterial growth yield in microgravity in limiting glucose or glycerol. Samples $(10 \mu l)$ of overnight cultures of the $E$. coli strain GC2852, cultivated in M63 medium containing $40 \mu \mathrm{g}$ kanamycin $\mathrm{ml}^{-1}$ and glucose or glycerol at $0.4 \%$, were sealed in glass ampoules, attached to a plastic matrix, and placed in polypropylene bags together with medium containing glucose or glycerol at four concentrations from 0.01 to $0.1 \%$. Ground and fight samples were inoculated at time-zero and allowed to grow for $24 \mathrm{~h}$ at $37^{\circ} \mathrm{C}$, permitting saturation, after which samples were cooled to $4{ }^{\circ} \mathrm{C}$, preventing further growth. (a) Growth yield, calculated from the $\mathrm{OD}_{600}\left(\right.$ an $\mathrm{OD}_{600}$ of 1 is equivalent to $254 \mu \mathrm{g}$ dry wt $\mathrm{ml}^{-1}$ ), for the triplicate flight samples cultivated in four limiting concentrations of glycerol. (b) Growth yield, calculated as in $(a)$, for all flight and ground cultures in glucose and glycerol; each point represents the mean of triplicate samples. (c) Cell concentration shown for all flight and ground cultures in glucose and glycerol; each point represents the mean of triplicate samples. $O$, Ground experiments; + , flight experiments. by breaking the ampoules at time-zero; growth was stopped $24 \mathrm{~h}$ later by lowering the temperature to $4{ }^{\circ} \mathrm{C}$. We chose two different carbon sources - glucose and glycerol - for our experiments. Glucose can be fermented, permitting anaerobic growth, whereas glycerol supports only aerobic growth.

The concentration of biomass in each sample was evaluated by measuring the optical density at $600 \mathrm{~nm}$, which is proportional to cell mass $\mathrm{ml}^{-1}$. The optical density measurements for the cells grown in limiting glycerol are shown in Fig. $2(a)$. It can be seen that the triplicate points are generally in good agreement; the higher dispersion at the lowest glycerol concentration is due to a slight, variable degree of cell lysis in the low density cultures of both flight and ground experiments. In Fig. 2(b), all the data are shown; each point represents the mean of the triplicate samples. It can be seen that the cell yield from glucose or glycerol was not affected in the space environment.

For each sample, the cell concentration was measured. Again, no significant differences were observed between flight and ground samples (Fig. $2 c$ and data not shown). The protein concentration was also measured in each sample. Once more, there were no significant differences between flight and ground samples (data not shown).

The constancy of the growth yield in space, in both cell mass and cell number, strongly suggests that there is no major economy of energy during growth in microgravity, implying that $E$. coli does not expend a significant part of its energy to combat gravity.

Previous authors have reported increased growth rates of micro-organisms in weightless conditions. Direct measurement of growth rate in the Cytos incubator presented technical problems. However, it has long been known that the mean cell mass (or volume) of $E$. coli cells during steady-state growth is a direct function of the richness of the medium: fast-growing cells are larger than slow-growing cells, with cell size ranging over a factor of at least five (Nanninga \& Woldringh, 1985). Thus cell volume at a single point in time is in a sense an instantaneous picture that directly reflects a kinetic parameter, the growth rate. The cells in the above experiments had stopped growing due to depletion of their carbon source. In reconstruction experiments, we have shown that when growth is arrested in this way, the mean cell volume is reduced to a constant proportion $(60 \%)$ of the steady-state volume in both glucose and glycerol (data not shown). The mean cell volume after growth arrest therefore provides a good quantitative estimate of the steady-state growth rate in the above cultures before growth arrest. It can be seen that there was no significant difference in cell volume between flight and ground cultures in either medium, with the volume being clearly smaller in the glycerol cultures (Fig. 


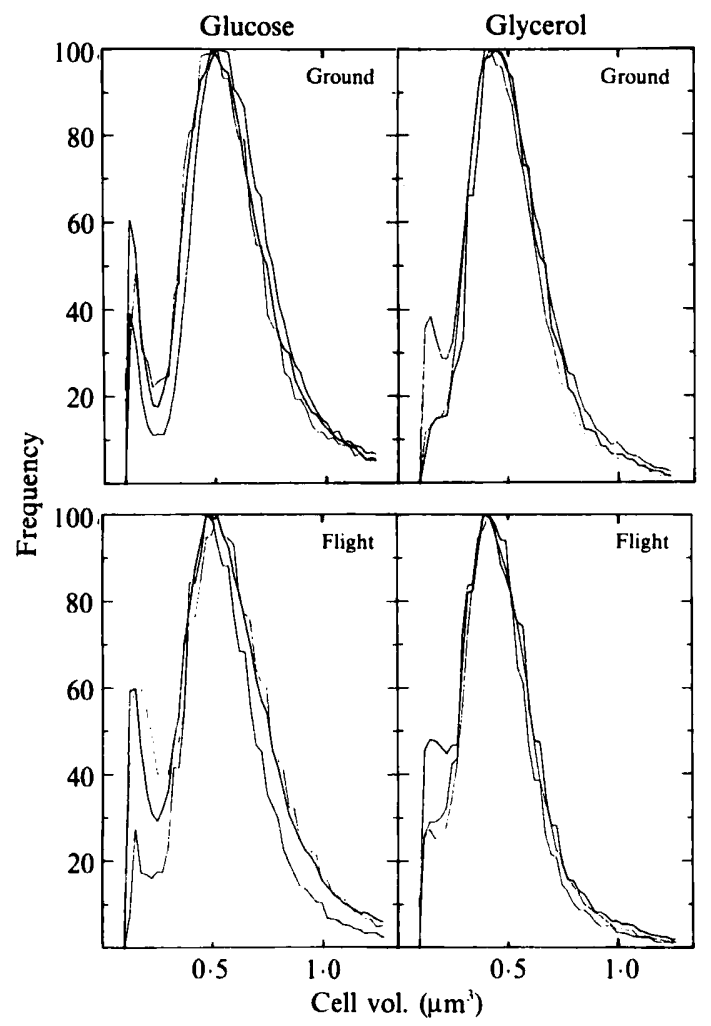

Fig. 3. Cell volume distribution after growth in glucose and glycerol. The samples shown in Fig. 2 were analysed in a Coulter counter Channelyzer.

3). Furthermore, observation of the cells in the phase contrast microscope revealed that cell morphology was normal as well.

Similar experiments were performed under conditions of hypergravity. Plastic bags with limiting concentrations of glucose or glycerol were inoculated and placed on a low-speed centrifuge, providing a total acceleration vector of 3 and $5 \mathrm{~g}$. The experiment was carried out in a $37{ }^{\circ} \mathrm{C}$ room for $36 \mathrm{~h}$. The growth yield was in all cases identical to the $1 \mathrm{~g}$ control (data not shown).

\section{SOS response}

Standard bacterial tests used to quantify genotoxicity are all based on a quantification, more or less direct, of the level of expression of the SOS response, which is induced by treatments that damage DNA. The regulation of the SOS response is now well understood at the molecular level (Walker, 1987); DNA damage creates singlestranded DNA, which forms a ternary complex with the RecA protein and ATP; this complex promotes cleavage of the LexA protein, which is the repressor of the SOS functions. To measure the genotoxicity of the space environment, we used a gene fusion in which lac $Z$, the structural gene of the enzyme $\beta$-galactosidase, is transcribed solely from the promoter of the SOS gene sfiA. Since $\beta$-galactosidase is extremely stable, evaluation of its specific activity, even days after the end of the experiment, is a direct reflection of the level at which the SOS response was expressed in the growing culture. The sfiA gene, which codes for a cell division inhibitor, is directly repressed by LexA and has a 50 -fold maximum induction ratio, the highest of any known SOS gene (Huisman \& D'Ari, 1981; Mizusawa et al., 1983). The same sfiA::lacZ fusion is the basis of the SOS Chromotest, which has been used to reveal SOS induction at extremely low doses of UV light and by heavy particle bombardment, including neutrons and alpha particles (Quillardet et al., 1982, 1989; Quillardet \& Hoinung, 1984).

We measured the level of SOS induction in bacteria

Table 1. Expression of a sfiA : : lacZ fusion in microgravity

An overnight culture of the E. coli strain GC4415 was prepared in LB broth containing $10 \mu \mathrm{g}$ tetracycline $\mathrm{ml}^{-1}$ and loaded into ampoules. To measure $\beta$ galactosidase specific activity in the exponential phase of growth, we stopped growth 90,180 or $270 \mathrm{~min}$ after inoculation by injecting the antibiotic chloramphenicol (final concentration $200 \mu \mathrm{g} \mathrm{ml}^{-1}$ ), contained in a second ampoule. Two samples were lost.

\begin{tabular}{|c|c|c|c|c|}
\hline \multirow[b]{2}{*}{$\begin{array}{l}\text { Time } \\
(\min )\end{array}$} & \multicolumn{2}{|c|}{ Ground } & \multicolumn{2}{|c|}{ Flight } \\
\hline & $\mathrm{OD}_{600}$ & $\begin{array}{c}\beta \text {-Galactosidase } \\
\text { activity }\end{array}$ & $\mathrm{OD}_{600}$ & $\begin{array}{c}\beta \text {-Galactosidase } \\
\text { activity }\end{array}$ \\
\hline 120 & $\begin{array}{l}0.030 \\
0.219\end{array}$ & $\begin{array}{l}78 \\
77\end{array}$ & $\begin{array}{l}0.409 \\
0.255 \\
0.530\end{array}$ & $\begin{array}{r}129 \\
75 \\
85\end{array}$ \\
\hline 180 & $\begin{array}{l}0.042 \\
0.606 \\
0 \cdot 310\end{array}$ & $\begin{array}{l}92 \\
92 \\
89\end{array}$ & $\begin{array}{l}0.950 \\
0.556 \\
0.783\end{array}$ & $\begin{array}{r}90 \\
102 \\
101\end{array}$ \\
\hline 270 & $\begin{array}{l}0.365 \\
0.366 \\
0.427\end{array}$ & $\begin{array}{r}104 \\
99 \\
128\end{array}$ & $\begin{array}{l}0 \cdot 724 \\
0 \cdot 539\end{array}$ & $\begin{array}{r}94 \\
113\end{array}$ \\
\hline
\end{tabular}


during exponential growth in the space environment. The results (Table 1) indicate that there was no significant increase in the level of expression of the SOS response in the culture grown in these conditions. We conclude that the radiation flux within the satellite was insufficient to cause major DNA damage to the bacteria. All measurements were during exponential growth, as indicated by the $\mathrm{OD}_{600}$, although the final optical density varied amongst triplicates, possibly because of variable injection of the inocula. Furthermore, the orbital inclination of $82^{\circ}$ subjected the satellite to the most intense radiation fluxes near the earth. Failure to cause detectable SOS induction is generally taken to mean that the treatment tested is not dangerous. This is a useful criterion for chemical products, but in the case of heavy particle radiation, whose biological effects are cumulative, a negative result cannot exclude potential danger during long periods of exposure, such as the 2-3 years that would be required for the first manned trip to Mars and back.

We would like to express our deep gratitude to Hervé Bozouklian and Sandy Gruss for their constant encouragement and invaluable help throughout this work. We thank Jacques Raffin for expert technical advice and are indebted to Sylvain Blanquet for introducing us to the world of space biology. We are grateful to Jean-Claude Deschepper and Claude Le Ludec for constructing and helping to design the low-speed centrifuge used in the hypergravity experiments. Ph. B. was the recipient of a post-doctoral fellowship from the Centre National des Études Spatiales. This work was financed principally by the CNES.

\section{References}

Bradford, M. (1976). A rapid and sensitive method for the quantification of microgram quantities of protein utilizing the principle of protein-dye binding. Analytical Biochemistry 72, 248254.

Cogoli, A., Tschopp, A. \& Fuchs-Bislin, P. (1984). Cell sensitivity to gravity. Science 225, 228-230.

D'ArI, R. \& Huisman, O. (1983). Novel mechanism of cell division inhibition associated with the SOS response in Escherichia coli. Journal of Bacteriology 156, 243-250.
GMÜNDER, F. K. \& CoGolI, A. (1988). Cultivation of single cells in space. Applied Microgravity Technology 1, 115-122.

HUISMAN, O. \& D'ARI, R. (1981). An inducible DNA replication-cell division coupling mechanism in E. coli. Nature, London 290, 797-799.

Huisman, O., D'ARI, R. \& GotTesman, S. (1984). Cell division control in Escherichia coli: specific induction of the SOS function SfiA protein is sufficient to block septation. Proceedings of the National Academy of Sciences of the United States of America 81, 4490-4494.

LeTAW, J. R., SilberberG, R. \& TSAO, C. H. (1987). Radiation hazards on space missions. Nature, London 330, 709-710.

Limouse, M., Manié, S., Konstantinova, I., Ferrua, B. \& Schaffar, L. (1991). Inhibition of phorbol ester-induced cell activation in microgravity. Experimental Cell Research (in the Press).

MenigmanN, H. D. \& LANGE, M. (1986). Growth and differentiation of Bacillus subtilis under microgravity. Naturwissenschaften 73, 415-417.

MilLeR, J. H. (1972). Experiments in Molecular Genetics. Cold Spring Harbor, NY: Cold Spring Harbor Laboratory.

Mizusawa, S., Court, D. \& GotTesman, S. (1983). Transcription of the sulA gene and repression by LexA. Journal of Molecular Biology 171, 337-343.

Montgomery, P. O'B., JR, CoOK, J. E., Reynolds, R. C., PAul, J. S., Hayflick, L., Stock, D., Schulz, W. W., Kimsey, S., Thirolf, R. G., Rogers, T. \& Cambell, D. (1978). The response of single human cells to zero-gravity. In Vitro 14, 165-173.

Nanninga, N. \& Woldringh, C. L. (1985). Cell growth, genome duplication, and cell division. In Molecular Cytology of Escherichia coli, pp. 259-318. Edited by N. Nanninga. London: Academic Press.

QUILLARDET, P. \& HOFNUNG, M. (1984). Induction by UV light of the SOS function sfiA in Escherichia coli strains deficient or proficient in excision repair. Journal of Bacteriology 157, 35-38.

Quillardet, P., Huisman, O., D'ARI, R. \& Hofnung, M. (1982). SOS Chromotest, a direct assay of induction of an SOS function in Escherichia coli $\mathrm{K}-12$ to measure genotoxicity. Proceedings of the National Academy of Sciences of the United States of America 79, 5971-5975.

Quillardet, P., Frelat, G., Nguyen, V. D. \& Hofnung, M. (1989). Detection of ionizing radiations with the SOS Chromotest, a bacterial short-term test for genotoxic agents. Mutation Research 216, 251-257.

Richoilley, G., Tixador, R., Gasset, G., Templier, J. \& Planel, H. (1986). Preliminary results of the "paramecium" experiment. Naturwissenschaften 73, 404-406.

Tixador, R., Richoilley, G., Raffin, J., Bost, R., Kojarinov, V. \& LEPSKYE, A. (1981). The Cytos biological experiments carried out on the soviet orbital station Salyut 6. Aviation Space and Environmental Medicine 52, 485-487.

WALKER, G. C. (1987). The SOS response of Escherichia coli. In Escherichia coli and Salmonella typhimurium, pp. 1346-1357. Edited by F. C. Neidhardt, J. L. Ingraham, K. B. Low, B. Magasanik, M. Schaechter \& H. E. Umbarger. Washington, DC: American Society for Microbiology. 